Jurnal Kependudukan Indonesia | Edisi Khusus Demografi dan COVID-19, Juli 2020 |27-32

\author{
JURNAL KEPENDUDUKAN INDONESIA
}

\author{
p-ISSN : 1907-2902 (Print) \\ e-ISSN : 2502-8537 (Online)
}

\title{
PERSEPSI MASYARAKAT AKAN PENTINGNYA SOCIAL DISTANCING DALAM PENANGANAN WABAH COVID-19 DI INDONESIA
}

\section{(THE PERCEPTION OF INDONESIANS CONCERNING THE IMPORTANCE OF SOCIAL DISTANCING AS AN EFFORT TO 'FLATTEN THE CURVE' OF COVID-19 IN INDONESIA)}

\author{
Nina Novira ${ }^{1 *}$, Rudi Iskandar ${ }^{2}$, Raehanul Bahraen ${ }^{3}$ \\ ${ }^{1}$ Universitas Negeri Medan Indonesia \\ ${ }^{2}$ Universitas Negeri Jakarta Indonesia \\ ${ }^{3}$ Universitas Negeri Mataram Indonesia \\ *Korespondensi penulis: ninanovira@unimed.ac.id
}

\begin{abstract}
COVID-19 has spread worldwide including Indonesia. The government responds by appealing to the public to implement social distancing $(s d)$ to contained the spread of the virus. However, without threats Concrete penalties and the absence of strict safeguards make the application of SD dependent on perception and compliance community only. Seeing the fact that some people continue their activities outside the home, various assumptions developing in the community. By using Google Form ${ }^{\circledR}$, this study aims to analyze perceptions the public on the importance of implementing SD as an effort to deal with Covid-19, confirmed the general assumptions that develops in the community, and traces the causes of the ineffectiveness of elementary school application. Research result shows that most of the community believes that adoption of SD is very important. However, that perception not always directly proportional to the appropriate behavior. The general perception is that those who stay out of the house are in the context of work and earning a living is not proven. Compared to attending invitations and stays organizing events that have been planned since before the plague, still worship in more houses of worship many cause people to leave the house.
\end{abstract}

Keywords: community perception, COVID-19, social distancing

COVID-19 pertama kali merebak di Kota Wuhan, Tiongkok pada akhir tahun 2019 (Li dkk., 2020; Riou \& Altahaus, 2020). Meskipun Pemerintah baru mengumumkan kasus pertama di Indonesia pada awal Maret 2020, banyak pihak percaya bahwa COVID-19 sudah jauh lebih dulu menjangkiti masyarakat Indonesia (Almuttaqi, 2020; Pranita, 2020; Massola, 2020). Segera setelah pengumuman resmi tersebut, pemerintah menghimbau agar masyarakat melakukan social distancing $(s d)$ yang diartikan sebagai pembatasan diri untuk keluar rumah, menghindari kerumunan, dan menjaga jarak fisik (Djalante dkk., 2020; Setiati \& Azwar, 2020). Sebagian masyarakat muslim merespons himbauan tersebut dengan mengatakan bahwa himbauan tersebut selaras dengan tuntunan Rasulullah Muhammad SAW dalam menanganani wabah penyakit menular (Rajab dkk, 2020). Kelompok ini kemudian banyak mengedukasi masyarakat akan pentingnya $s d$ baik dari segi medis maupun dari segi mengikuti tuntunan Rasulullah dalam 
menangani wabah (Subarkah, 2020; Gugus Tugas Percepatan Penganganan COVID-19, 2020; Mukharom \& Aravik, 2020). Kelompok lain mengedukasi masyarakat lewat sejarah penanganan wabah-wabah di masa lalu, seperti wabah flu spanyol dan kolera di Eropa dan wabah pes di Malang di masa penjajahan Belanda (Griffin \& Denholm, 2020; Mukhaer, 2020; Fizriyani, 2020).

Penerapan $s d$ di Indonesia tidak disertai dengan ancaman hukuman atau penertiban menyeluruh oleh aparat yang berwenang (Subarkah, 2020; Davina, 2020). Karena itu, implementasinya sangat bergantung pada kesadaran masyarakat sendiri. Sementara itu, ketika di satu sisi mayoritas masyarakat sepakat bahwa $s d$ sangat penting diterapkan, namun di sisi lain mereka tidak sepaham dengan perlu tidaknya tempat ibadah ikut ditutup (Dimedjo, 2020). Masuknya bulan Ramadhan menambah keinginan sebagian masyarakat untuk beribadah di masjid dan mushola. Di saat yang sama, kebutuhan masyarakat untuk mencari pemasukan guna menyambung hidup memaksa sebagian masyarakat untuk tetap melakukan keseharian seperti biasa. Selain itu terdapat pula kelompok yang menganggap remeh penyebaran COVID-19 serta tidak mengindahkan protokol kesehatan yang telah ditetapkan Badan Kesehatan Dunia (WHO) (Mashabi, 2020) dan menganggap COVID-19 sebagai sebuah konspirasi dan rekayasa (Nursaniyah, 2020). Penelitian ini berupaya untuk menjawab dan menjelaskan persepsi masyarakat akan pentingnya penerapan social distancing sebagai upaya penanganan wabah COVID19 di Indonesia berdasarkan karakteristik sosial ekonomi, mengkonfirmasi asumsi umum yang berkembang di masyarakat tentang penerapan $s d$ serta menganalisa penyebab kurang efektifnya penerapan kebijakan tersebut.

Dengan menggunakan fasilitas Google Form ${ }^{\circledR}$ sebagai angket yang disebarkan melalui media sosial dan relasi di berbagai kota di Indonesia pada rentang waktu 24 April - 10 Mei 2020, penelitian ini berhasil mengumpul 2.828 respons dari 32 Provinsi di Indonesia. Sebaran responden penelitian ini disajikan di Tabel 1 .

Tabel 1. Sebaran Responden

\begin{tabular}{cccccc}
\hline Provinsi & Prosentase & Provinsi & Prosentase & Provinsi & Prosentase \\
\hline Jawa Barat & 26,87 & Sulawesi Selatan & 2,01 & Kalimantan Utara & 0,53 \\
DKI Jakarta & 13,96 & Lampung & 1,76 & Bangka/Belitung & 0,49 \\
Jawa Tengah & 7,49 & Kalimantan Barat & 1,73 & Kalimantan Tengah & 0,49 \\
Banten & 7,39 & Sumatera Selatan & 1,48 & Papua & 0,39 \\
Jawa Timur & 6,65 & Kepulauan Riau & 0,88 & Bengkulu & 0,21 \\
Sumatera Utara & 4,77 & Kalimantan Selatan & 0,81 & Gorontalo & 0,21 \\
DIY & 4,06 & Sulawesi Tenggara & 0,74 & NTT & 0,17 \\
NTB & 3,43 & Aceh & 0,63 & Maluku Utara & 0,14 \\
Sumatera Barat & 3,11 & Bali & 0,6 & Sulawesi Utara & 0,07 \\
Kalimantan Timur & 3,11 & Jambi & 0,56 & Sulawesi Barat & 0,01
\end{tabular}

Sumber: Data Primer, 2020

Penelitian ini menggunakan 6 parameter berdasarkan tipe perilaku dan aktifitas untuk menganalisa persepsi masyarakat tentang pentingnya penerapan $s d$ di Indonesia dan implementasinya pada beberapa perilaku terkait $s d$, yaitu pertanyaan harfiah mengenai pentingnya $s d$, mengurangi keluar rumah, beribadah di rumah ibadah, menghadiri undangan hari raya atau pesta, penyelenggaraan acara yang sudah direncanakan, dan rencana mudik lebaran. Setiap parameter diberi nilai $1-5$ yang menggambarkan kondisi terrendah hingga tertinggi. Nilai akhir kemudian dibagi menjadi 5 kelas.
Sebanyak 87,9 persen responden menganggap penerapan sd sangat penting dengan 36,8 persen responden memberikan nilai maksimal untuk seluruh parameter dan hanya sebanyak 0,6 persen yang masuk pada kelas 2. Hal ini menunjukkan bahwa sejatinya mayoritas masyarakat menganggap penting penerapan $s d$ dalam penanganan COVID-19. Namun kami tidak berhenti sampai disitu. Kami juga menganalisa asumsi yang banyak berkembang di masyarakat tentang perbedaan perilaku masyarakat dalam menyikapi kebijakan $s d$ yang dikaitkan dengan pendidikan, jenis pekerjaan, besarnya pendapatan, dan dampak $s d$ pada 
pendapatan. Lebih lanjut, kami menganalisa penyebab utama kurang efektifnya penerapan kebijakan $s d$ di masyarakat. Karena yang diharapkan adalah pemahaman akan ketidakpatuhan terhadap kebijakan $s d$, maka data yang dianalisa adalah data-data dengan kelas dan nilai rendah.

Dari 17 responden yang masuk pada kelas 2 (terrendah), hanya 6 responden yang berprofesi sebagai pekerja harian. Sebanyak 15 responden menyatakan tetap beribadah di rumah ibadah seperti biasa dan 2 responden menyatakan sedikit mengurangi. Sebanyak 14 responden menyatakan tetap akan mudik lebaran walaupun tidak ada perbaikan berarti. Profil lengkap responden yang masuk ke dalam kelas 2 dipaparkan pada Tabel 2.

Tabel 2. Profil Responden Dengan Nilai Akhir Kelas 2

\begin{tabular}{|c|c|c|c|c|c|c|c|c|}
\hline Pekerjaan & Domisili & Pendidikan & $\begin{array}{l}\text { Anggapan } \\
s d\end{array}$ & $\begin{array}{l}\text { Keluar } \\
\text { Rumah }\end{array}$ & $\begin{array}{l}\text { Ibadah } \\
\text { di } \\
\text { Rumah } \\
\text { Ibadah }\end{array}$ & $\begin{array}{l}\text { Menghadiri } \\
\text { perayaan } \\
\text { agama/pesta }\end{array}$ & $\begin{array}{c}\text { Penyelenggaraan } \\
\text { acara }\end{array}$ & $\begin{array}{l}\text { Mudik } \\
\text { Lebaran }\end{array}$ \\
\hline Guru/Dosen/Peneliti & $\begin{array}{l}\text { Sumatera } \\
\text { Barat }\end{array}$ & SMA & 1 & 1 & 1 & 5 & 1 & 1 \\
\hline Guru/Dosen/Peneliti & $\begin{array}{l}\text { DKI } \\
\text { Jakarta }\end{array}$ & Sarjana & 5 & 5 & 1 & 1 & 1 & 1 \\
\hline Ibu rumah tangga & Jawa Barat & Mahasiswa & 4 & 5 & 1 & 1 & 1 & 1 \\
\hline Ibu rumah tangga & Banten & $\begin{array}{l}\text { Pasca } \\
\text { Sarjana }\end{array}$ & 5 & 5 & 1 & 1 & 1 & 1 \\
\hline Ibu rumah tangga & $\begin{array}{l}\text { Sumatera } \\
\text { Utara }\end{array}$ & Sarjana & 5 & 5 & 1 & 1 & 1 & 1 \\
\hline Pedagang grosiran & $\begin{array}{l}\text { Jawa } \\
\text { Tengah }\end{array}$ & SMA & 1 & 1 & 1 & 5 & 2 & 1 \\
\hline Pedagang rumahan & $\begin{array}{l}\text { Jawa } \\
\text { Timur }\end{array}$ & SD & 2 & 1 & 1 & 1 & 5 & 2 \\
\hline Pedagang rumahan & $\begin{array}{l}\text { Sumatera } \\
\text { Utara }\end{array}$ & Sarjana & 2 & 2 & 1 & 2 & 2 & 1 \\
\hline Pedagang rumahan & Jawa Barat & Mahasiswa & 3 & 2 & 1 & 3 & 3 & 1 \\
\hline Pekerja harian & Jawa Barat & $\begin{array}{l}\text { Pasca } \\
\text { Sarjana }\end{array}$ & 1 & 1 & 1 & 5 & 3 & 1 \\
\hline Pekerja harian & NTB & Sarjana & 1 & 1 & 1 & 5 & 4 & 1 \\
\hline Pekerja harian & Jawa Barat & Sarjana & 2 & 2 & 2 & 2 & 2 & 1 \\
\hline Pekerja harian & $\begin{array}{l}\text { Jawa } \\
\text { Timur }\end{array}$ & SMA & 2 & 4 & 1 & 3 & 2 & 1 \\
\hline Pekerja harian & $\begin{array}{l}\text { Sumatera } \\
\text { Barat }\end{array}$ & SMA & 3 & 1 & 1 & 1 & 3 & 1 \\
\hline Pekerja harian & Jawa Barat & Sarjana & 4 & 3 & 1 & 1 & 1 & 3 \\
\hline $\begin{array}{l}\text { Pengusaha } \\
\text { export/import }\end{array}$ & $\begin{array}{l}\text { Jawa } \\
\text { Timur }\end{array}$ & Mahasiswa & 1 & 4 & 1 & 1 & 5 & 1 \\
\hline $\begin{array}{l}\text { PNS/Pegawai } \\
\text { Kantoran dengan gaji } \\
\text { tetap }\end{array}$ & $\begin{array}{l}\text { Sumatera } \\
\text { Utara }\end{array}$ & Sarjana & 3 & 3 & 2 & 1 & 1 & 2 \\
\hline
\end{tabular}

Sumber: Data Primer, 2020

Keterangan rentang penilaian: $\quad$ 1: nilai minimal yang dapat berarti sangat tidak penting, dan tetap seperti biasa;

5: nilai maksimal yang dapat berarti sangat penting, dan sangat tidak dilakukan

Terdapat 14 responden yang memberi jawaban sangat tidak penting untuk pertanyaan harafiah apakah menurut mereka kebijakan $s d$ penting dilakukan sebagai upaya penanggulangan COVID-19 di Indonesia. Namun, dari 14 responden tersebut, hanya 5 responden yang menjawab sama sekali tidak mengurangi untuk pertanyaan mengurangi keluar rumah. Bahkan 5 responden lain mengaku sangat mengurangi keluar rumah. Hal ini menunjukkan bahwa perilaku keluar rumah mereka hanya sedikit mempengaruhi dan dipengaruhi persepsi tentang pentingnya kebijakan $s d$. Hal ini diperkuat dengan 
adanya 15 dari 30 responden yang mengaku sama sekali tidak mengurangi keluar rumah, namun menganggap kebijakan $s d$ sangat penting diterapkan. Di saat reponden yang menganggap kebijakan $s d$ tidak penting sebanyak 14 responden, terdapat 30 responden menjawab sama sekali tidak mengurangi keluar rumah.

Dilihat dari jenis pekerjaan, sebanyak 50 persen dari 30 responden yang sama sekali tidak mengurangi keluar rumah tersebut memiliki pekerjaan yang memungkinkan untuk dikerjakan dari rumah, seperti Guru/Dosen/Peneliti, Ibu Rumah Tangga, dan PNS/Pegawai Kantoran dengan Gaji Tetap. Hanya 11 responden yang memiliki pekerjaan sebagai pekerja harian yang sering diasumsikan sebagai kelompok yang tidak mengurangi keluar rumah dan melanggar anjuran $s d$. Dilihat dari tingkat pendidikan, terdapat 2 mahasiswa, 9 sarjana, 3 pasca sarjana, dan hanya 1 SD, sedangkan responden yang berpendidikan SD sebanyak 8 responden.

Dari 193 responden yang berprofesi sebagai pekerja harian, sebanyak 74 persen menjawab $s d$ sangat penting dan hanya 1,5 persen yang menjawab sangat tidak penting. Meskipun nilainya turun ketika ditanya mengenai mengurangi keluar rumah, yaitu sebanyak 44,6 persen menyatakan sangat mengurangi dan 5,7 persen menyatakan tidak mengurangi sama sekali, namun nilai akhir menunjukkan nilai yang lebih tinggi. Sebanyak 70,5 persen pekerja harian menempati kelas 5 dan hanya 3,1 persen yang menempati kelas terrendah, yaitu kelas 2 .

Dari 543 responden yang berpenghasilan kurang dari Rp. 1.000.000,-, hanya 4 responden yang menganggap kebijakan $s d$ tidak penting dan hanya 15 responden yang sama sekali tidak mengurangi keluar rumah. Dari 68 responden pekerja harian yang berpenghasilan kurang dari Rp. 1.000.000,-, hanya satu responden yang menganggap kebijakan $s d$ tidak penting dan 6 reponden yang sama sekali tidak mengurangi keluar rumah.

Hal ini menunjukkan bahwa perilaku mengurangi keluar rumah tidak dipengaruhi oleh jenis pekerjaan, rendahnya pendidikan maupun rendahnya penghasilan. Jika bukan karena pekerjaan dan mencari pemasukan, lalu apakah yang menyebabkan kurang efektifnya penerapan kebijakan $s d$ ?
Sebanyak 29 responden menyatakan akan tetap menghadiri perayaan keagamaan massal dan atau pesta dan 56 responden akan tetap menyelenggarakan perayaan, pesta, atau seminar yang telah direncanakan sejak sebelum pandemi. Di saat yang sama, terdapat 137 responden yang menyatakan tetap akan mudik lebaran dan 191 responden yang menyatakan tetap beribadah di rumah ibadah seperti biasa. Dari seluruh pertanyaan, beribadah di rumah ibadah dan mudik lebaran mendapat jawaban dilaksanakan seperti biasa terbanyak dengan perbedaan kuantitas yang cukup signifikan. Mungkinkah hasrat masyarakat untuk tetap beribadah di rumah ibadah menjadi penyebab utama tidak efektifnya implementasi $s d$ di Indonesia? Hasil penelitian menunjukkan bahwa tetap beribadah ke rumah ibadah sebagai faktor yang paling membuat masyarakat tetap keluar rumah. Namun, penelitian yang diluncurkan awal Mei 2020 ini belum mempertimbangkan keputusan pemerintah untuk mendorong strategi pemulihan ekonomi dan terlupa untuk mempertimbang eforia masyarakat dalam menyambut lebaran. Penelitian ini juga tidak menanyakan perilaku keluar rumah lain selain ibadah dan menghadiri undangan. Hal ini sayangnya menjadikan penelitian ini sedikit bias.

\section{KESIMPULAN}

Penjabaran di atas menghantarkan kita kepada beberapa benang merah. Yang pertama, bahwa persepsi umum akan pentingnya penerapan $s d$ dalam menangani wabah tidak mampu mengontrol masyarakat agar berperilaku sesuai dengan persepsi umum tersebut. Seseeorang bisa saja berpersepsi bahwa kebijakan sd sangat penting, namun tidak dapat menahan diri untuk keluar rumah guna berbagai kepentingan. Benang merah kedua yaitu bahwa persepsi umum tentang mereka yang tidak patuh berasal dari profesi, tingkat pendidikan, atau tingkat penghasilan tertentu tidak terbukti. Mereka yang dianjurkan bahkan wajib bekerja dari rumah pun tidak mengurangi keluar rumah dan beraktifitas seperti biasa. Benang merah ketiga, meskipun bias, menunjukkan satu hal. Banyaknya yang mengaku sangat mengurangi keluar rumah namun tetap beribadah di rumah ibadah menunjukkan bahwa di satu sisi, masyarakat Indonesia sangat religius. Sisi religuisitas tersebut mendorong masyarakat agar lebih dekat pada tuhan di masa sulit. Namun di sisi lain, perilaku tetap beribadah di rumah 
Persepsi Masyarakat akan Pentingnya..| Nina Novira dkk.

ibadah ini dapat juga merupakan dampak dari propaganda yang mengolok-olok masyarakat yang tertib menahan diri untuk keluar rumah termasuk ke rumah ibadah. Untuk menjawab bias yang terjadi, peneliti akan melakukan studi lebih lanjut.

\section{UCAPAN TERIMA KASIH}

Tim Peneliti berterima kasih kepada seluruh pihak yang telah membantu penyebaran dan pengisian kuisioner daring kami.

\section{DAFTAR PUSTAKA}

Almuttaqi, A. I. (2020, Maret 23). The Omnishambles of COVID-19. THC Insights No. 13, The Habibie Center.

Davina, D. (2020, Maret 18). Tak Terapkan Lockdown Pemerintah Kampanyekan Social Distancing, Apa Bedanya? Kompas TV. https://www.kompas.tv/article/71830/ini-yangharus-dipahami-perbedaan-social-distancingdengan-lockdown.

Dimedjo, E. (2020, Maret 20). Soal Corona, UAS: Kenapa Masjid Ditutup Mal Tidak. Tagar.id. https://www.tagar.id/soal-corona-uas-kenapamasjid-ditutup-mal-tidak.

Djalante, R., Lassa, J., Setiamarga, D., Sudjatma, A., Indrawan, M., Haryanto, B., Mahfud, C., Sinapoy, M.S., Djalante, S., Rafliana, I., Gunawan, L.A., Suriarti, G.A.K., \& Warsilah, H. (2020). Review and analysis of current responses to COVID-19 in Indonesia: Period of January to March 2020. Progress in Disaster Science 6, 19. https://doi.org/10.1016/j.pdisas.2020.100091.

Fizriyani, W. (2020, April 12). Saat Kolonial Remehkan Wabah. Republika. Diakses melalui https://republika.co.id/berita/q8rt8s393/saatkolonial-remehkan-wabah.

Griffin, D., \& Denholm, J. (2020). This isn't the first global pandemic, and it won't be the last. Here's what we've learned from 4 others throughout history. The Conversation . https://theconversation.com/this-isnt-the-firstglobal-pandemic-and-it-wont-be-the-last-hereswhat-weve-learned-from-4-others-throughouthistory-136231.
Gugus Tugas Percepatan Penanganan COVID-19. (2020). Anjuran Menghindari Wabah dan Tidak Menyebarkannya. Gugus Tugas Percepatan Penanganan COVID-19 [Brosur]. https://COVID19.go.id/edukasi/masyarakatumum/anjuran-menghindari-wabah-dan-tidakmenyebarkannya-telah-menjadi-salah-satusabda-rasulullah-saw.

Li, Q., Guan, X., Wu, P., Wang, X., Zhou, L., Tong, Y., Ren, R., Leung, K.S.M., Yau, E.H.Y., Wong, J.Y., Xing, X., Xiang, N., Wu, Y., Li, C;, Chen, Q., Li, D., Liu, T., Zhao, J.,... Feng, Z. (2020). Early Transmission Dynamics in Wuhan, China, of Novel Coronavirus-Infected Pneumonia. The New England Journal of Medicine, 382 (13), 1199-1207. https://doi.org/ 10.1056/NEJMoa2001316.

Mashabi, S. (2020, Maret 20). Istana: Banyak Anak Muda Anggap Remeh Virus Corona. Kompas.com. https://nasional.kompas.com/read/2020/03/23/1 1104741/istana-banyak-anak-muda-anggapremeh-virus-corona.

Massola, J. (2020, Mei 7). 'Not allowed to do testing': governor says Jakarta was tracking COVID-19 cases in January. The Sydney Morning Herald. https://www.smh.com.au/world/asia/notallowed-to-do-testing-governor-says-jakartawas-tracking-COVID-19-cases-in-january20200507-p54qnh.html.

Mukhaer, A. A. (2020, April 27). Selain COVID-19, Inilah 5 Wabah Paling Mematikan dalam Sejarah. National Geographic. https://nationalgeographic.grid.id/read/1321208 40/selain-COVID-19-inilah-5-wabah-palingmematikan-dalam-sejarah?page $=$ all.

Mukharom, \& Aravik, H. (2020). Kebijakan Nabi Muhammad Saw Menangani Wabah Penyakit Menular dan Implementasinya Dalam Konteks Menanggulangi Coronavirus COVID-19. SALAM; Jurnal Sosial \& Budaya Syar-i 7 (3), 239-246. https://doi.org/10.15408/sjsbs.v7i3.15096

Nursaniyah, F. (2020, Mei 7). Temukan Bukti Konspirasi COVID-19, Jerinx: RS di Luar Negeri Kosong, Kata Teman Saya. Pikiran Rakyat. $\quad$ https://bekasi.pikiranrakyat.com/nasional/pr-12378258/temukanbukti-konspirasi-COVID-19-jerinx-rs-di-luarnegeri-kosong-kata-teman-saya. 
Jurnal Kependudukan Indonesia | Edisi Khusus Demografi dan COVID-19, Juli 2020 | 27-32

Pranita, E. (2020, Mei 10). Diumumkan Awal Maret, Ahli: Virus Corona Masuk Indonesia dari Januari. Kompas.com. https://www.kompas.com/sains/read/2020/05/11 /130600623/diumumkan-awal-maret-ahli--viruscorona-masuk-indonesia-dari-januari.

Rajab, A. J., Nurdin, M. S., \& Mubarak, H. (2020). Tinjauan Hukum Islam Pada Edaran Pemerintah dan Mui dalam Menyikapi Wabah Covid-19. Bustanul Fuqaha. Jurnal Bidang Hukum Islam 1 (2), 156-173. https://doi.org/10.36701/bustanul.v1i2.143

Riou, J., \& Althaus, C.L. (2020). Pattern of early human-to-human transmission of Wuhan 2019 novel coronavirus (2019-nCoV), December 2019 to January 2020. Euro Surveillance, 25 (4), https://doi.org/10.2807/15607917.ES.2020.25.4.2000058 .
Setiati, S., \& Azwar, M. K. (2020). COVID-19 and Indonesia. Acta Med Indonesia. Indonesian Journal of International Medicine 52 (1), 84-89. http://www.actamedindones.org/index.php/iji $\mathrm{m} /$ article/view/1426/pdf

Subarkah, M. (2020, Maret 20). Teladan Nabi Muhammad Mencegah Wabah. Republika. https://republika.co.id/berita/q7hqrm385/teladan -nabi-muhammad-mencegah-wabah.

Subarkah, T. (2020, Maret 23). Social Distancing di KRL: Longgar di Peron, Padat di Kereta. Media Indonesia.

https://mediaindonesia.com/read/detail/298322social-distancing-di-krl-longgar-di-peron-padatdi-kereta. 